\title{
ORTHODOX RELIGIOUS IDENTITY AND EUROPEAN VALUES: SUPPLEMENTS OR OPPOSITES?
}

\author{
Korzhov H., \\ $P h D$ in Sociology, \\ Associate Professor at the Sociology Department \\ National Technical University of Ukraine "Igor Sikorsky Kyiv Polytechnic Institute"
}

The processes of European integration taking place on various levels and in diverse spheres of life are full of contradictions and obstacles. What bonds present-day inhabitants of Europe at the level of mass consciousness, the so-called European values are an object of heated discussion. Religion and religious values may well unite and contribute to the sense of common collective identity at different levels. At the same time, religion may lead - and in actuality often led - to ferocious and bloody conflicts. Christianity that has determined civilizational identity for the overwhelming majority of European nationstates is not unified. Orthodoxy tradition of Christianity is conceived of by elites and general public in the countries of 'core Europe' as a rather contradictory phenomenon. The author attempts to answer a research question: Does Christian Orthodox tradition exhibited in people's religious identity contradict to the modern European values and, subsequently, slow down European integration? This article uses secondary quantitative approach to undertake an exploratory analysis and test religious identity effects on European value systems in six countries with predominantly Orthodox religious profile. Preliminary findings testify that two phenomena at question are not antipodes, in opposition to what is widely believed. The Orthodox faithful differ from non-believers and adherents of other confessions by several value attitudes, but these dissimilarities validate more pro-democratic and pro-European values of Orthodox believers. In particular, the latter show stronger support for democratic values, including democratic political system, and civic political culture. Strong Orthodox believers hold a more consistent system of values and worldview than non-believers, who mostly demonstrate consumerist and ego-centric attitudes.

Key words: religious identity, religiosity, religious worldview, religious behavior, Orthodox religion, European values.

Introduction. During centuries religion has played a role of utmost importance in the creation of symbolic borders and formation of national, regional, and collective identities. Religions greatly contributed to the sense of collective identity at different levels. It is Christianity that has determined civilizational identity for the overwhelming majority of European nation-states. However, Europe has always been influenced by the mixture of religious heritages in which Christianity occupies substantial but by no means overriding place being evidently supplemented by Jewish and Muslim traditions. Moreover, Christianity itself is not homogeneous and represents a complex combination of different confessions. The socio-cultural border which emerged between Western and Eastern Christianity as a result of the church split in 1054 has divided the European space for many centuries.

The processes of European integration and the formation of the EU create historic opportunities for the restoration of the once united cultural and symbolic space and the construction of European identity among all of the nations of the continent. However, this process is full of contradictions and difficulties. In countries of the so-called Old Europe secular and church elites as well as general public conceive of the Eastern Christianity as essentially different, specific, and incompatible with European historical, cultural and mental heritage. On their part, Orthodox clergy and laity in many countries, including members of the EU, e.g. Greece, hold ambivalent attitudes towards the processes of European integration. The latter is usually perceived as being initiated and headed by the Catholic-Protestant West and constituting a grave threat to the Orthodox identity, its unity and uniqueness. In this context Europe is identified by bearers of Orthodox identity with materialist Anglo-Saxon civilization and liberalism [23, p. 86].

The presented paper aims to explore possible interconnections between Orthodox religiousness and European values from individual, micro-level perspective. This provides a much needed addition to the majority of available studies whose prime foci are on institutional and structural prerequisites and dimensions of changes in religious situation in post-socialist, European and global perspective $[4 ; 7 ; 8 ; 9 ; 12 ; 13$; $14 ; 17 ; 23]$. Pavlo Kutuev reconstructs the evolution of sociological research programs of development 
and modernization providing a general scholarly framework for analyzing the role of church institutions and transformations of religious ideas and ideologies [28]. Maxim Yenin scrutinizes changes in ideological landscapes while modernization moves forward from the first modernity stage to the second one [27].

That stream of research which concentrates on individual dimensions of religiosity tends to explore religious consciousness, identity, worldview, attitudes and behavior inside the sacral sphere of religious values and practices [e.g., 9; 11; 16]. Hence, wider implications and correlates of religiosity remain beyond the scope of most research.

The author of the given study seeks to answer the general research question: Does Christian Orthodox tradition exhibited in people's religious identity contradict to the modern European values and, subsequently, to European integration? This issue will be considered at the level of mass consciousness by examining those attitudes, views, opinions, and values that are shared by public in few countries which populations by majority belong to the Orthodox religion. By applying research strategy to several countries, the presented research aims to broaden exploratory perspective and make it more cross-nationally oriented. For the time being, there are only a few works where comparative quantitative approach to religious issues in societies with Eastern Christianity tradition is applied. In this context it is worthwhile to note works by Tomka [17; 18], Yelensky [26], J.-P. Willem [23]. Irena Borowik [1; 2; 3] and Larissa Titarenko [16] provides a critical overview of religious landscape in three post-Soviet countries - Belarus, Russia, and Ukraine - after the collapse of the USSR, compares level and nature of religiosity, and, the mixed, syncretic nature of religious belief and social practices among the post-Soviet populations. Borowik makes conclusion that the so-called 'religious revival' is in fact a "return to tradition", an attempt "to reconstruct the continuity of historical experience" [1, p. 505]. She also finds lots of features in common between religious changes in Eastern and Western Europe [1, p. 506]. The French researcher Jean-Paul Willaime [23] makes a thorough analysis of the specificity of the church status in various European countries, laïcité (the French term for secularity) as a fundamental European value, the role of religion and church in the processes of European integration.

Since the 1990-s a significant body of literature dedicated to the so-called 'religious revival' has been formed. A number of authors tried to shed light on diverse manifestations of the transformations in religious sphere of post-communist countries [32] and looked for a sociological system of empirical indicators to identify religious renaissance [31]. Quite a few studies are concerned with the interrelations of separate dimensions of religiousness with different kinds of values [11;12;30] and identities, in particular national and European ones $[5 ; 6 ; 13]$. A number of publications seek to thoroughly examine the specificity of Orthodox religiosity in post-communist societies [10;15]. Finally, some studies devoted to single countries are of particular importance to the presented research as well [24; 25; 29].

The countries selected for the presented study differ in the level of institutionalization of their relationships with the European Union. Some of them, such as Bulgaria, Romania, and Cyprus, are members of the EU, another one is an official candidate (Serbia), while the rest, post-Soviet countries are usually referred to as European neighbors (Moldova and Ukraine). Most of them are post-socialist countries that share similar historical experience. Under socialism they have come through the policy of enforced secularization in the form of state-imposed atheism and communist persecution of religion. Last two decades we have been witnessing the phenomenon of 'religious revival' (the growth of the number of the faithful, openings of new churches and return of old ones under the jurisdiction of religious authorities, the achievement of real religious freedom, increase in the number of church attendance, loyalty of political authorities to church, etc.). However, this external, visual part of religious life does not adequately reflect what in reality is going on behind the scene of 'religious renaissance'.

The general question will be examined in two interrelated aspects each of which represents a sub-question to be answered in the paper:

1) What are the level and nature of religiosity in Orthodox societies?

2) Do Orthodox believers differ from non-Orthodox believers and non-believers in their value attitudes, particularly those which are in most cases associated with Europe and called 'European values'?

The paper discusses the aforementioned problems, by and large, on the basis of a secondary analysis of empirical data combined within the framework of few international comparative surveys ${ }^{1}$.

By examining religious situation in post-socialist countries both inside and outside of the EU one can answer the question of great theoretical and practical importance if there are common values shared by several European nations, not only by those comprising the EU. The research is aimed at the illumination of religious and sociopolitical value orientations of people in several countries with the prevalence of the Orthodox among the religious population. In this respect we follow the Weberian tradition of studying

\footnotetext{
${ }^{1}$ In the presented research the results of the European Values Survey (1999), World Values Surveys (2006), and International Social Survey Programme (2008) for six countries with predominantly Orthodox population (Romania, Bulgaria, Cyprus, Serbia, Moldova, and Ukraine) are used. Source: WORLD VALUES SURVEY 1981-2008 OFFICIAL AGGREGATE v.20090901, 2009. World Values Survey Association (www.worldvaluessurvey.org). Aggregate File Producer: ASEP/JDS, Madrid.
} 
religiosity by focusing on actual religious consciousness and practices of adherents rather than examining exclusively religious dogmas, theology and church official documents; "practical incentives for action" sources of which should be looked for in "psychological and pragmatic religious ties" [22, c. 397].

\section{Religion and religiosity in the Orthodox countries}

The epoch of post-communism is marked not only by more economic and political freedom, but also by religious liberty. Lots of commentators hastened to declare the advent of new religious revival in the countries of the former socialist block. The openings of new churches and return of old ones under the jurisdiction of religious authorities, the achievement of real religious freedom and, concomitantly, the increase in the number of church attendance as well as loyalty in religious issues demonstrated by many political leaders were some, mostly visible signs of the changes embracing religious field. However, this external, visual part of religious life does not adequately reflect what in reality is going on behind the scene of 'religious renaissance'.

The countries in study are characterized by the existence of a long-lasting hegemonic religious tradition of Orthodoxy. However, they are not homogeneous in this respect. In particular, Moldova with 93,3\% of the population declaring their belonging to Orthodox church according to the 2004 national census is strongly influenced by two historical and religious traditions - Russian and Romanian. This cultural heritage currently manifests itself in the co-existence of two church jurisdictions - the Moldovan Orthodox Church, subordinated to the Russian Orthodox Church, and the Orthodox Church of Bessarabia, subordinated to the Romanian Orthodox Church. Both of them claim to be the national church of the country. There is even more complicated situation in Ukraine where three Orthodox churches and a numerous religious minority of the Greek-Catholics coexist which is a consequence of borderland location of the country at the crossroads of different cultures and civilizations. Bulgaria, being a country with the dominant tradition of Orthodoxy and with the oldest Slavic Orthodox church (according to the 2001 census most of the population (82.6\%) self-identify as Orthodox Christian), also has a sizeable Muslim minority (12.2\%), which makes its religious landscape quite diverse.

Let us now turn to the data that reflect the level and character of religiosity in six societies (See Tables 1 and 2). All the studied countries are characterized by very high level of self-declared religiosity which is rather typical for Orthodox societies.

The level of religiosity in six Orthodox countries (population, \%)

\begin{tabular}{|l|c|c|c|c|c|c|}
\hline \multicolumn{1}{|c|}{ Indicator of religiosity } & Romania & Bulgaria & Cyprus & Serbia & Moldova & Ukraine \\
\hline $\begin{array}{l}\text { 1. Orthodox self-identification } \\
\text { (among the whole population) }\end{array}$ & 86.8 & 76.0 & 89.1 & 85.0 & 93.3 & 67.3 \\
\hline $\begin{array}{l}\text { 2. Belonging to } \\
\text { Orthodox (among the religious } \\
\text { population) }\end{array}$ & 87.1 & 87.4 & 51.8 & 91.6 & 94.3 & 87.8 \\
\hline $\begin{array}{l}\text { Consciousness } \\
\text { 3. Religious person }\end{array}$ & 93.4 & 63.4 & 60.8 & 85.5 & 84.1 & 82 \\
\hline $\begin{array}{l}\text { 4. Importance of religion } \\
\text { (very important-important) }\end{array}$ & $58-32.5$ & $18.6-31.9$ & $51.3-26.3$ & $25.7-40.9$ & $31.8-41.2$ & $17-38.6$ \\
\hline 5. God is very important in life & 66.3 & 12.2 & 57.6 & 21.7 & 41.2 & 26.8 \\
\hline 6. Moments of prayer (yes) & 95.8 & 24.3 & 73.7 & 64.4 & 85.7 & 62.8 \\
\hline $\begin{array}{l}\text { 7. Religious faith as } \\
\text { an important child quality }\end{array}$ & 62.8 & 17.7 & 33.8 & 25.1 & 41.6 & 15.1 \\
\hline $\begin{array}{l}\text { Behavior } \\
\text { 8. Membership of church or } \\
\text { religious organization } \\
\text { (active - inactive member) }\end{array}$ & $5.4-4.4$ & $1.8-2.5$ & $6.4-7.7$ & $3.9-15.5$ & $12.9-19.7$ & $5.4-11.5$ \\
\hline $\begin{array}{l}\text { 9. Attendance of religious } \\
\text { services (weekly - monthly) }\end{array}$ & $27.2-18.7$ & $6.5-8.8$ & $16.1-11.4$ & $11.1-16.3$ & $12.8-12.8$ & $9.2-12.2$ \\
\hline
\end{tabular}

Source: WORLD VALUES SURVEY 1981-2008 OFFICIAL AGGREGATE v.20090901, 2009. World Values Survey Association (www.worldvaluessurvey.org). Aggregate File Producer: ASEP/JDS, Madrid. Data refer to 2008.

As a rule, Orthodox believers turn out to be more religious by their self-identification than the rest of the population. In some cases - Bulgaria and especially Ukraine - the difference becomes very noticeable and significant. However, the level of religiosity among the predominantly Orthodox countries varies

\footnotetext{
${ }^{2}$ Source: US Department of State. 2018. Report on International Religious Freedom. https://www.state.gov/reports/2018-report-oninternational-religious-freedom/.
}

ВІСНИК НТУУ «КПІ». Політологія. Соціологія. Право. Випуск 3 (43) 2019 
substantially: the proportion of those who regard themselves religious fluctuate between 60.8 (Cyprus) and $93.4 \%$ (Romania) among the general public and $62.2-96.1 \%$ among the Orthodox (the polar cases are Cyprus and Ukraine). Besides, self-identification as a religious person is too unreliable indicator in itself to make conclusions about the level and nature of religiosity in Orthodox societies. This is explained by specificity of contemporary religious situation and by historical factors having influenced the position of Orthodox church and religion in these countries.

The level of religiosity in six Orthodox countries (Orthodox population, \%)

Table 2

\begin{tabular}{|l|c|c|c|c|c|c|}
\hline \multicolumn{1}{|c|}{ Indicator of religiosity } & Romania & Bulgaria & Cyprus & Serbia & Moldova & Ukraine \\
\hline $\begin{array}{l}\text { Consciousness } \\
\text { 1. Religious person }\end{array}$ & 94.2 & 70.5 & 62.2 & 89.4 & 85.6 & 96.1 \\
\hline $\begin{array}{l}\text { 2. Importance of religion } \\
\text { (very important-important) }\end{array}$ & $57.4-33.9$ & $17.6-34.2$ & $56.8-28.6$ & $27.2-41.8$ & $31.1-42.4$ & $17.9-46.2$ \\
\hline 3. God is very important in life & 66.2 & 13.2 & 57.4 & 22.9 & 40.6 & 30.1 \\
\hline 4. Moments of prayer & 96 & 24.9 & 77 & 65.9 & 86.7 & 72.2 \\
\hline $\begin{array}{l}\text { 5. Religious faith } \\
\text { as an important child quality }\end{array}$ & 62 & 5.1 & 50.5 & 25 & 41.7 & 15.4 \\
\hline $\begin{array}{l}\text { Behavior } \\
\text { 6. Membership of church } \\
\text { or religious organization } \\
\text { (active - inactive member) }\end{array}$ & $4-4.2$ & $1.5-2.7$ & $10.2-13.1$ & $3.3-15.2$ & $10.8-20.6$ & $4.7-15.1$ \\
\hline $\begin{array}{l}\text { 7. Attendance of religious } \\
\text { services (weekly - monthly) }\end{array}$ & $22.9-19.7$ & $6.8-10.5$ & $21.6-19.3$ & $10.1-17$ & $10.5-13.3$ & $7.8-15.7$ \\
\hline
\end{tabular}

Source: WORLD VALUES SURVEY 1981-2008 OFFICIAL AGGREGATE v.20090901, 2009. World Values Survey Association (www.worldvaluessurvey.org). Aggregate File Producer: ASEP/JDS, Madrid. Data refer to 2008.

By using a bunch of empirical indicators one can obtain a more precise picture of the level and character of religiosity. According to several variables used in the WVS, which refer both to the realm of religious consciousness and that of religious behavior, the most religious countries are Romania and Cyprus with Moldova being close to them. The following variables were used in comparative analysis: 1) five indicators of religious consciousness - religious identity, the subjective importance of religion and God in respondent's life, praying, and necessity to bring up religious faith in a child, and 2) two indicators of religious conduct membership in church or religious organization and attendance of religious services. The most secularized country in terms of both people's world-view and religious behavior is Bulgaria. In case of Cyprus one can observe a quite interesting peculiarity - a sharp contrast between a rather low level of religious self-identity of Orthodox adherents and high level of religiosity according to a group of empirical indicators. Orthodox Cypriots can be referred to as believers with rather strong traditional religious attitudes, such as frequent praying, attributing great importance to God and religion and putting high emphasis on religious components in kid's upbringing. Moreover, they demonstrate a high level of church attendance with each fifth attending it once a week or more often and another $20 \%$ - monthly. This is unusually high rate for advanced countries and for Orthodox societies as well. It is worth noting that Cyprus differs from the rest of the countries under consideration in several important aspects: 1) there are two hegemonic religious traditions here - Orthodox and Muslim with almost equal range of influence; 2) Cyprus did not come through the period of protracted and forced secularization, persecution for religious belief.

Similar indicators are typical of Romania which can be also recognized as a society with strong elements of traditional religiosity. The same conclusion but with some reservations is true with respect to Moldova. The transitory position with elements of traditional religious and secularized consciousness and behavior is occupied by Serbia and Ukraine, while Bulgaria, as was shown before, is a mostly secularized Orthodox country. The differences in the level and nature of religiosity among these countries may well be explained by the specificity of modernization processes. In particular, it is worth noting that countries with stronger elements of traditional religiosity are generally less modernized and characterized by the lower level of urbanization (Moldova - 42, Serbia - 52, Romania - 54, Ukraine - 68, Cyprus - 70, Bulgaria $71 \%$ ), though this regularity is not linear. For instance, Cyprus has one of the biggest levels of urbanization and at the same time one of the lowest indicators of secularization.

Thus, the presence of Orthodox hegemonic religious tradition does not preclude from having rather substantial differences in the level and nature of religiosity. The countries of Eastern and Southern Europe at hand have similar experience of Communist past and delayed modernization which may well shape social identity and value orientations of their peoples [18, p. 253-254]. Peoples with similar modernization 
experience may have essentially varying patterns of religiosity, religious identity and values. Thus, secularization is not such a consistent, homogeneous and unvarying process as it is often presented. It has diverse substance in different historical epochs and socio-cultural contexts. In other words there is no one secularity, there are many secularities. Additionally secularity is a dynamic phenomenon, it is in a state of permanent changes. These changes have both internal and external logic, being influenced by development of religion and churches themselves, on one hand, and being part of wider cultural, political, legal, economic and social processes, on the other. The various understanding of the role and place of religion and church in the spheres of politics, education and social life in general affects the essence of secularity and the normative legitimization of religious values in society. In our case, Bulgaria appears to be most secular among the other countries by several indicators (importance of God, religious faith as family value, frequency of praying). In the meantime, the overwhelming majority of Bulgarians think about themselves as religious people, the importance of religion remains at a rather high level, and the church attendance figures are almost on a par with other, more religious societies.

As opposed to a dominant paradigm of secularization, Thomas Luckmann posits that "religion is not a passing phase in the evolution of mankind but a universal aspect of the conditio humana. Appearing under different socio-structural conditions in various historical forms, it remains a constituent element of human life, bonding the individual human being, most particularly its experience of transcendence, to a collective view of the good life" [9, p. 276]. Seen from such an angle the so-called religious revival pointed out by many observers of post-communist reality has to be interpreted as a collective and individual search for a better - in spiritual and moral terms - life in conditions of deep societal crisis accompanied by existential, value-normative, and ideological vacuum. This approach treats the reasons for the rise of interest in religion in broader terms than it is done within the theoretical approach associated with the idea of cultural trauma [14].

\section{Value priorities of Orthodox adherents}

What constitutes a system of European values is an issue worth of conducting a separate study. With the creation and further enlargement of the EU this problem was given additional impetus and provoked heated discussions on different levels and among different audiences. Due to the limited space we put this question aside and follow that system of values which is officially recognized and codified in the EU law. The Treaty of Lisbon explicitly declares the importance of values shared by all the member states for their unity, and respect of and support for these values are regarded as a necessary prerequisite for any country seeking to become a member of the EU. Among the fundamental values of the European Union the following ones are specified: respect for human dignity, freedom, democracy, equality, the rule of law, respect for human rights, including the rights of persons belonging to minorities. In addition, Article 2 of the Treaty states that "These values are common to the Member States in a society in which pluralism, non-discrimination, tolerance, justice, solidarity and equality between women and men prevail" [19].

Accordingly to the postulated values we delineate the logic of our consequent research attempting to shed light on the question: Do Orthodox believers differ from non-Orthodox believers and non-believers in their value attitudes, particularly those which are in most cases associated with Europe and called 'European values'? The WVS-2005 allows for examining this issue by comparing value priorities of the above mentioned groups of the population in our countries. We captured European values by using a set of empirical indicators to measure the following values: social equality, including gender equality, democracy and civic activism, secularity, socio-economic values of private property and competition, ecological stability, trust and tolerance, moral permissiveness as well as post-materialist orientations.

We started with the value of equality that has a more specific manifestation in the WVS - gender equality. We constructed 'gender equality index' based on four variables that measure people's attitudes to social roles and status of men and women. The variables are measured on the basis of the questions: 1) "Do you agree or disagree with the following statement? When jobs are scarce, men should have more right to a job than women" (three categories: agree, neither, disagree). 2) "People talk about the changing roles of men and women today. For each of the following statements I read out, can you tell me how much you agree with each. Do you agree strongly, agree, disagree, or disagree strongly? On the whole, men make better political leaders than women do" 3) "A university education is more important for a boy than for a girl". 4) "Men make better business executives than women do". Factor analysis showed that all four variables measure only one underlying factor. The extracted factor explains $56 \%$ of the variance in all four variables. Subsequently the extracted factor was saved as a variable with a mean of 0 and a standard deviation of 1 . As is seen from the Table 3 , there is a statistically significant difference among three compared groups. The Orthodox believers demonstrate mostly pro-equal, in comparison with other groups within these societies, attitudes concerning the position of men and women in a society. Nevertheless their evaluations are close to neutral point which confirms that they are not ready to accept the idea and social practice of gender equality typical of more advanced European societies. 
Table 3

Value orientations of non-religious, non-Orthodox religious, and Orthodox adherents, WVS, 2005

\begin{tabular}{|c|c|c|c|c|}
\hline Indicator of value & $\begin{array}{l}\text { Non- } \\
\text { religious }\end{array}$ & $\begin{array}{l}\text { Religious } \\
\text { non- } \\
\text { Orthodox }\end{array}$ & $\begin{array}{l}\text { Religious } \\
\text { Orthodox }\end{array}$ & Total \\
\hline $\begin{array}{l}\text { Gender equality (regression factor score) } \\
\text { (means between groups) }\end{array}$ & $-.105^{\star}$ & $.015^{\star}$ & $.021^{*}$ & \\
\hline $\begin{array}{l}\text { Incomes should be made more equal - } \\
\text { We need larger income differences as incentives }\end{array}$ & $19-42$ & $34-33.7$ & $27.2-30.7$ & $27.6-32$ \\
\hline $\begin{array}{l}\text { In the long run, hard work usually brings a better } \\
\text { life - Hard work doesn't generally bring success }\end{array}$ & $34.5-22.7$ & $47.3-16.1$ & 40.9-19.2 & $41.3-19$ \\
\hline $\begin{array}{l}\text { Tolerance to out-groups } \\
\text { (\%, not mentioned by respondent as that } \\
\text { s/he would not like to have as neighbors) } \\
\text { Drug addicts }\end{array}$ & 12.7 & 16.3 & $17^{*}$ & 16.6 \\
\hline People of a different race & 86.9 & 83.4 & 80.4 & 81.3 \\
\hline People who have AIDS & 50.6 & 44.7 & 48.1 & 47.8 \\
\hline Homosexuals & 45.4 & 36.4 & 39 & 39.1 \\
\hline People of a different religion & 89 & 85.3 & $82.3^{*}$ & 83.3 \\
\hline Heavy drinkers & 23.6 & 33.9 & $28.3^{*}$ & 28.8 \\
\hline Unmarried couples living together & 91.8 & 75.4 & 87.5 & 86 \\
\hline $\begin{array}{l}\text { Democracy } \\
\text { Importance of democracy (1-absolutely } \\
\text { unimportant, 10-very important) (mean) }\end{array}$ & $7.83^{*}$ & $8.64^{*}$ & $8.19^{*}$ & 8.23 \\
\hline $\begin{array}{l}\text { Respect for individual human rights } \\
\text { is guaranteed ( } 1 \text {-yes, } 4-n 0)\end{array}$ & 2.98 & 2.56 & 2.85 & 2.82 \\
\hline $\begin{array}{l}\text { Level of democracy in a country } \\
\text { (1-very low, 10-very high) }\end{array}$ & $4.43^{*}$ & $5.71^{*}$ & $5.28^{*}$ & 5.28 \\
\hline
\end{tabular}

The Orthodox faithful also show stronger support for democratic values, including democratic political system, and civic political culture. The roots of these phenomena most probably lie in the strong association between religious and anti-communist attitudes emerged in the period of post-socialist transformation. It is not occasional that believers with democratic views are more often found among the supporters of right-wing and centrist rather than leftist parties. As one commentator argues, "the majority of those of a democratic orientation returned to religion, seeing anti-communism in it above all" [1, p. 500]. However, one cannot reduce pro-democratic values of the believers to the heritage of anti- and post-communism. Religious outlook makes the faithful more sympathetic to that social system which assures more humanistic relationships and possibilities for human activities and self-actualization. In addition, strong Orthodox believers hold a unified, consistent system of values and world-view in contrast to non-believers, who mostly demonstrate consumerist and ego-centric attitudes, which eventually make the former stronger supporters of European value system.

Conclusions. Religiosity in various Orthodox countries has substantial features in common, namely: a high level of declared religious belief and low level of church attendance, in particular, and religious practice, in general (the phenomenon of so-called believing without belonging). The level of individual religiosity among the Orthodox believers is higher than that of churched religiosity. At the same time the Orthodox faithful in different countries substantially differ in terms of their religious consciousness or outlook. This relates to the level of religiosity (its spread and strength). Only two countries out of six at question are characterized by a stronger religious standpoint among Orthodox than among representatives of other confessions (Cyprus and Serbia). The share of coherently religious people whose self-identification is additionally supported by consistent religious judgments, opinions, and attitudes, i.e. religious outlook, and religious conduct is extremely low [21]. The majority of Orthodox believers can be characterized as those confessing without believing. One can observe the politicization of religiosity, the invasion of political sphere in religious life. Church is increasingly considered by political elites as an instrument of political legitimization and mobilization of masses.

Findings demonstrate that strong Orthodox believers hold a more unified, consistent system of values and world-view than non-believers, who mostly demonstrate consumerist and ego-centric attitudes. They are characterized by a stronger support for democratic values, including democratic political system, and civic political culture. All things considered, in countries with deep and lengthy Orthodox tradition value 
orientations of the Orthodox make them stronger supporters of European value system than non-believers and representatives of other religions.

The foregoing results are a small step forward in an interesting, controversial, and understudied area of investigation. Much remains to be done in this field. Further research will help to shed light on the complex, multi-leveled structure of Orthodox religious identity and on its relationships with national and European orientations. It is badly needed to find out how different categories of Orthodox faithful (individually religious and churched, nominal or cultural and devout, etc.) refer to Europe-associated values. More empirical studies of the interconnections between religious consciousness and European values are needed to track their developments and effects in dynamics. Particularly, it is worthwhile to continue studying the issue on the basis of data coming from later waves of cross-national projects and to cover more nations. Additionally, in-depth, qualitatively oriented sociological and anthropological research would be especially appropriate in the context of the explication of such issues as differentiation between external and internal religiosity (T.Adorno) (or internalized and institutionalized in G.Allport's terms) among the Orthodox in its interrelatedness with value orientations and pro-European attitudes, people's subjective understandings and interpretations of religiousness among believers (in various confessions) and non-believers.

\section{Коржов Г. Православна релігійна ідентичність і європейські цінності: за чи проти?}

Процеси європейської інтеграції, що відбуваються на різних рівнях і в різних сферах життя, сповнені суперечностей і перешкод. Те, що пов'язує сучасних жителів Європи на рівні масової свідомості, так звані європейські цінності, є предметом бурхливих дискусій. Релігія і релігійні цінності можуть успішно об'єднувати й робити внесок до відчуття загальної колективної ідентичності на різних рівнях. Водночас релігія може призвести - і насправді саме так часто й відбувалося - до жорстоких і кривавих консрліктів. Християнство, яке визначило цивілізаційну ідентичність більшості європейських національних держав, не $є$ монолітним. Православна традиція християнства сприймається елітами й широкою громадськістю в країнах «старої Європи» як досить суперечливе явище. Автор намагається відповісти на дослідницьке питання: чи суперечить християнська православна традиція, що проявляє себе в релігійній ідентичності своїх послідовників, сучасним європейським цінностям і, як наслідок, чи не перешкоджає вона європейській інтеграції?

У статті використовується вторинний кількісний аналіз, у рамках якого на прикладі шести країн із переважно православним релігійним профілем робиться спроба верифрікувати гіпотезу про взаємозв'язок між православною релігійною ідентичністю і системою європейських цінностей. Попередні результати свідчать про те, що два розглянуті явища не є антиподами, як стверджує широко розповсюджена думка. Православні віруючі відрізняються від невіруючих і прихильників інших конфесій декількома ціннісними установками, причому виявлені відмінності підтверджують наявність у представників домінуючої християнської традиції більш демократичних і європейських цінностей. Зокрема, останні надають сильнішу підтримку демократії, включаючи демократичну політичну систему та громадянську політичну культуру. Православні віруючі дотримуються більш послідовної системи цінностей і світогляду, ніж невіруючі, які в основному демонструють споживчі й егоцентричні погляди.

Ключові слова: релігійна ідентичність, релігійність, релігійний світогляд, релігійна поведінка, православна релігія, європейські цінності.

\section{References:}

1. Borowik I. 2002. Between Orthodoxy and Eclecticism: On the Religious Transformations of Russia, Belarus and Ukraine. Social Compass, 49 (4): 497-508.

2. Borowik I. 2006a. Orthodoxy Confronting the Collapse of Communism in Post-Soviet Countries. Social Compass, 53(2): 267-278.

3. Borowik I. 2006b. Religions, Churches and Religiosity in Post-Communist Europe. Kraków : NOMOS.

4. Casanova J. 1994. Public Religions in the Modern World. Chicago: Chicago University Press.

5. Cerutti F. and S. Lucarelli. 2008. The search for a European identity: values, policies and legitimacy of the European Union. London: Routledge. 232 p.

6. Deflem M. and F. Pampel. 1996. The Myth of Postnational Identity: Popular Support for European Unification. Social Forces, 75 (1): 119-143.

7. Inglehart R. 1997. Modernization and Postmodernization: Cultural, Economic and Political Change in 43 Societies. Princeton : Princeton University Press. 
8. Joas H. 2009. The Future of Christianity. Sotsiologicheskie issledovaniya, 11: 78-88.

9. Luckmann T. 2003. Transformations of Religion and Morality in Modern Europe. Social Compass, 50 (3): 275-285.

10. Marsh C. 2005. Russian Orthodox Christians and Their Orientation toward Church and State. Journal of Church and State, 47: 545-561.

11. Polak R., Rosta G. Religion and values in Eastern and Central Europe. In: Máté-Tóth A., Rosta G. (eds.) Focus on Religion in Central and Eastern Europe: A Regional View. Berlin, Boston: Walter de Gruyter. P. 33-74.

12. Pollack D., Müller O., Pickel G. (eds.). 2016. The Social Significance of Religion in the Enlarged Europe: Secularization, Individualization and Pluralization. London, New York : Routledge.

13. Spohn W. 2009. Europeanization, Religion and Collective Identities in an Enlarging Europe: A Multiple Modernities Perspective. European Journal of Social Theory, 12(3): 358-374.

14. Sztompka P. 2000. Cultural Trauma. The Other Face of Social Change. European Journal of Social Theory, 3(4): 449-466.

15. Sutton J. and W. van den Bercken (eds.). 2003. Orthodox Christianity and Contemporary Europe. Leuven : Uitgeverij.

16. Titarenko L. 2008. On the Shifting Nature of Religion during the Ongoing Post-Communist Transformation in Russia, Belarus and Ukraine. Social Compass, 55(2): 237-254.

17. Tomka M. 2011. Expanding Religion: Religious Revival in Post-Communist Central and Eastern Europe. Berlin, New York: Walter de Gruyter.

18. Tomka M. 2006. Is Conventional Sociology of Religion Able to Deal with Differences between Eastern and Western European Developments? Social Compass, 53(2): 251-265.

19. Treaty of Lisbon http://eur-lex.europa.eu/JOHtml.do?uri=OJ:C:2007:306: SOM:EN:HTML.

20. US Department of State. 2018. Report on International Religious Freedom. https://www.state.gov/ reports/2018-report-on-international-religious-freedom/.

21. Биченко А., Дудар Н. Релігійність українського суспільства: рівень, характер, особливості. Національна безпека і оборона. 2002. № 10. С. 14-21.

22. Вебер М. Господарська етика світових релігій. Вступ. Вебер М. Соціологія. Загальноісторичні аналізи. Політика. Київ, 1998. С. 397-436.

23. Віллем Ж.-П. Європа та релігії. Ставки XXI століття. Київ : Дух і Літера, 2006. 331 с.

24. Дудар Н., Шангіна Л. Віра й релігія в житті українців. Національна безпека. 2000. № 10. С. 83-98.

25. Дудар Н., Шангіна Л. Релігія і церква в суспільному житті України. Національна безпека і оборона. 2002. № 10. C. 6-13.

26. Єленський В.Є. Релігія після комунізму. Релігійно-соціальні зміни в процесі трансформації центрально- та східноєвропейських суспільств - фокус на Україні. Київ : НПУ ім. М.П. Драгоманова, 2002. $419 \mathrm{c}$.

27. Єнін М. Ідеологічні трансформації в суспільстві другого Модерну. Сучасні суспільні проблеми у вимірі соціології управління. Серія «Соціологія» : збірник наукових праць ДонДУУ. Донецьк, 2012. Т. XIII. Вип. 217. С. 165-171.

28. Кутуєв П.В. Трансформації модерну: інституції, ідеї, ідеології : монографрія. Херсон : Гельветика, 2016.

29. Міщенко М. Особливості сприйняття ідеологем прихильниками різних політичних течій. Соціологія: теорія, методи, маркетине. 2017. № 3. С. 89-101.

30. Паращевін М. Вплив релігійності на поширеність цінності традиціоналізму. Соціологія: теорія, методи, маркетине. 2000. № 3.

31. Рязанова Л. Релігійний ренесанс: спроба соціологічної діагностики. Соціологія: теорія, методи, маркетина. 2001. № 4. С. 114-125.

32. Сідоркіна О.М. Релігійна свідомість в Україні у системі сучасних суспільних трансформацій. Вісник Національного авіаційного університету. Серія "Філософрія. Культурологія» : збірник наукових праць. Київ : Вид-во Національного авіаційного університету «НАУ-друк», 2009. № 1 (9). С. 178-181. 